\title{
舌下腺に発生した多形腺腫の一例
}

\author{
太田之博 ${ }^{1)} \cdot$ 木村哲雄 $^{1)}$ ・ 小牧誠史 ${ }^{2)}$ \\ 原田丈司 ${ }^{1)} \cdot$ 小林千恵 ${ }^{1)}$
}

\section{A case of pleomorphic adenoma in the sublingual gland}

\author{
OTA Yukihiro $^{1)} \cdot$ KIMURA Tetsuo $^{1)} \cdot$ KOMAKI Masashi $^{2)}$ \\ HARADA Takeshi ${ }^{1)} \cdot$ KOBAYASI Chie $^{1)}$
}

\begin{abstract}
Pleomorphic adenoma is the most common tumor arising in the salivary glands. Most cases of pleomorphic adenoma occur in the parotid gland, followed by the submandibular gland and minor salivary gland. However, pleomorphic adenoma of the sublingual gland is quite rare. One study has reported that only $0.08 \%$ of pleomorphic adenomas occur in the sublingual gland.

We present a case of pleomorphic adenoma in the sublingual gland. A 34-year-old Japanese woman had a swelling localized in the floor of the mouth. We surgically extirpated the tumor under general anesthesia. Pleomorphic adenoma was diagnosed on intraoperative frozen section examination. The tumor was encapsulated and isolated from the surrounding tissues, consistent with the preoperative MRI findings. As of 1 year 9 months after operation, there has been no evidence of recurrence.
\end{abstract}

Key words: pleomorphic adenoma（多形腺腫）, salivary gland tumor（唾液腺腫瘍）, sublingual gland（舌下腺）

\section{緒 \\ 言}

多形腺腫は唾液腺腫瘍のなかで最も発生頻度の高い良性 腫瘍で，その発生率は全唾液腺腫瘍の約 $60 \%$ 程度といわ れている1)。その多くは耳下腺に発生し，ついで顎下腺， 口蓋部小唾液腺での発生が多く, 舌下腺での発生は極めて まれで $0.08 \%$ との報告もある ${ }^{2)}$.

今回我々は, 舌下腺に生じた多形腺腫を経験したので報 告する.

\section{症例}

患 者：34 歳, 女性.

主 訴: 右口底部腫瘤.

1) 大阪警察病院柬科口腔外科

(主任：木村哲雄部長)

2) 大阪大学大学院茵学研究科顎口腔病因病態制御学講座 (口腔外科学第一教室)

(主任：古郷幹彦教授)

${ }^{1)}$ Department of Dentistry, Oral and Maxillofacial Surgery, Osaka Police Hospital (Chief: Dr. KIMURA Tetsuo)

${ }^{2)}$ The First Department of Oral and Maxillofacial Surgery, Osaka University, Graduate School of Dentistry (Chief: Prof. KOGO Mikihiko)

受付日：2008年 8 月 5 日

採択日：2009年 7 月 28 日
初 診：2007 年 11 月.

既往歴, 家族歴：特記事項なし.

現病歴：2007 年 7 月頃から右側口底部に無痛性の腫瘤 を認めたため, 近病院㐘科を受診し, 精査, 加療目的に当 科へ紹介受診となった.

現 症:

口腔外所見; 顔貌は左右対称, 所属頸部リンパ節の腫脹 および圧痛は認めなかった。

口腔内所見; 右口底部に直径約 $1.5 \mathrm{~cm}$ の境界明睹, 可動 性で弾性軟の腫瘤を認めた（写真 1$)$. 自発痛や圧痛はなく 右側ワルトン管開口部からの唾液の流出も良好であった. また, 舌の運動障害や味覚, 知覚異常も認めなかった.

臨床検査所見：異常所見なし。

MRI 所見：右側口底部に T1 強調画像にて低信号, T2 強 調画像にて高信号を示す境界明瞭で内部は一部不均一な腫 瘤を認めた. また造影 MRI 画像にて被膜様構造物の造影 が認められた (写真 $2 \mathrm{~A}, \mathrm{~B}, \mathrm{C})$.

臨床診断：右側舌下腺良性腫瘍.

処置および経過：2007 年 11 月 28 日全身麻酔下にて右 側舌下腺腫瘍摘出術を行った。術中所見により, 腫瘤はワ ルトン管との癒着を認めず, 舌下腺内に存在しており腫瘍 周囲の舌下腺を含めて摘出術を行った. 術中迅速組織検査 
にて多形腺腫との病理組織診断を得たため追加切除等は行 わなかった. 現在術後 1 年 9 か月が経過しているが再発な く, 経過良好である.

摘出標本の肉眼的所見: 摘出標本は $15 \times 13 \times 11 \mathrm{~mm}$ 大, 弾性軟, 表面は平滑で被膜を有し舌下腺内に存在して いた (写真 3).

病理組織学的所見：腫瘤は薄い線維性被膜で全周を被わ れており (写真 4A), 被膜外への腫瘍細胞の進展は認めら れなかった (写真 $4 \mathrm{~B}$ ). 腫瘍は部分的に軟骨様成分を含み, アルシアンブルー染色陽性の粘液腫様の間質を多量に伴っ ていた (写真 4C). 腫瘍細胞の大部分は類円形から紡鍾形 で，核の偏在傾向のある異型性の乏しい腫瘍性筋上皮細胞 が豊富な, 間質を伴う網状パターンの増殖を認める像から 成り, 小囊胞の形成が認められた (写真 4D). また部分的 には好酸性物質を腔内に認める導管上皮細胞と周囲の腫瘍

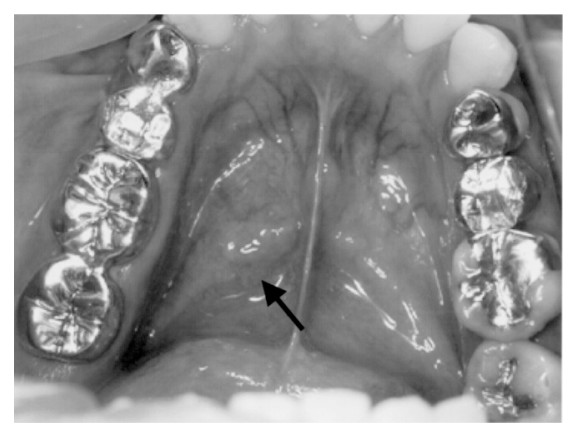

写真 1 初診時口腔内写真 右口底部に直径約 $1.5 \mathrm{~cm}$ の境界明 瞭，可動性で弾性軟の腫瘤を認めた。
性筋上皮細胞の配列からなる二相構造も認められた（写真 4E).

病理組織学的診断：多形腺腫.

$$
\text { 考察 }
$$

多形腺腫は全唾液腺腫瘍のなかで最も発現頻度が高い良 性腫瘍とされており, その発生率はArmed Forces Institute of Pathology (AFIP $)^{2)}$ は $49.0 \%$, 坂下ら ${ }^{3)}$ は $54.5 \%$, 山 田ら ${ }^{4)}$ は $57.1 \%$ と報告している. 好発部位は耳下腺が最 も多く, 舌下腺での発生は非常にまれとされている.また, AFIP は 12859 例の唾液腺腫瘍のうち舌下腺腫瘍は 47 例 $(0.4 \%)$ で,このうち多形腺腫は 10 例 $(0.08 \%)$ であり, 33 例 $(70 \%)$ が悪性腫瘍であった ${ }^{2)}$ とも報告している (表 1). 本邦における多形腺腫の舌下腺での発生率は井上 $5^{5 ）}$ が 102 例中 1 例 $(0.98 \%)$, 坂下ら ${ }^{3)}$ が 170 例中 1 例 $(0.6 \%)$, 白川ら ${ }^{6)}$ が 191 例中 2 例 $(1.0 \%)$ と報告してい る(表 2).

当科において過去 17 年間に経験した喠液腺腫瘍 68 例の うち舌下腺に発生した腫瘍は 6 例でそのうち多形腺腫は本 症例の 1 例のみであり, その他 5 例はすべて悪性腫瘍であ った（表 3)。これはAFIP あるいは本邦での報告例と類似 した結果であった.

このように舌下腺腫瘍は, 発生頻度が非常に低いにもか かわらず, 発現した腫瘍が悪性腫瘍である可能性が非常に 高いということが考察される.

唾液腺腫瘍の画像診断としては超音波検査, 唾液腺造影, CT, MRI, 核医学などが行われているが, 最近の画像診断 機器の精度向上により超音波, MRI を第一選択として診断 を進めていると報告されている ${ }^{7)}$. 今回は舌下腺腫瘍であ
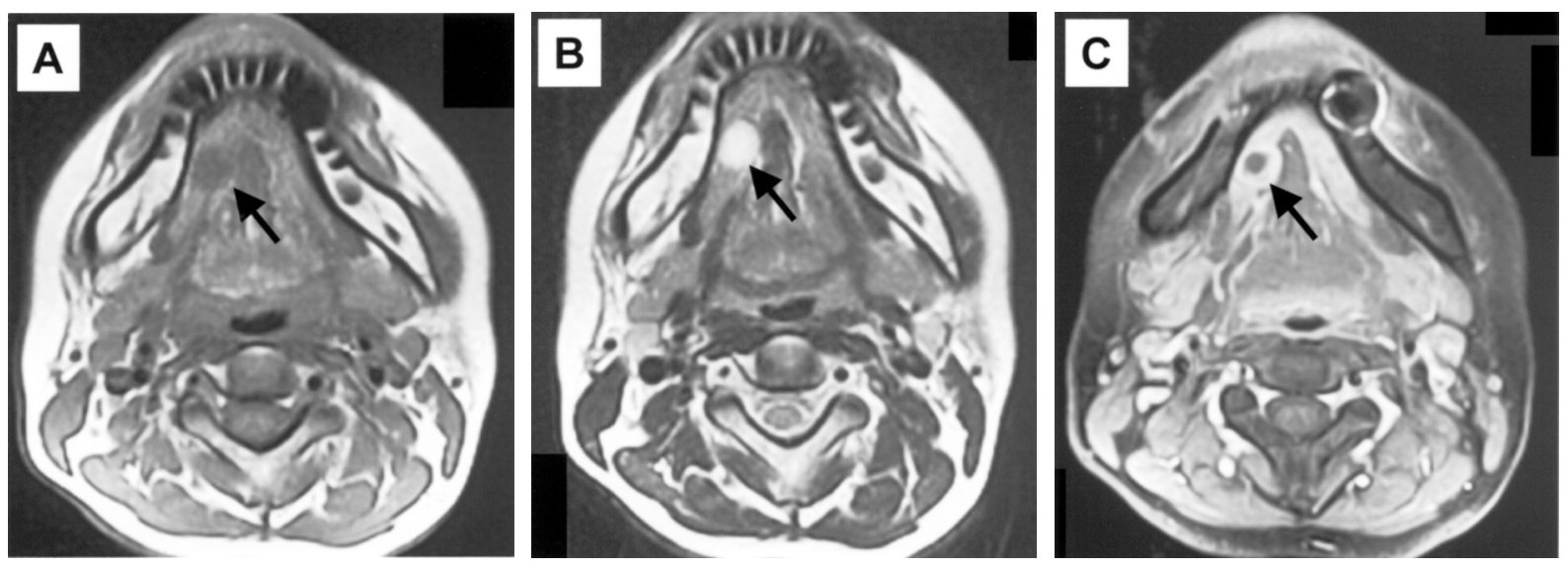

写真 2 MRI 画像

A：T1 強調画像にて低信号を示し, 内部が一部不均一な境界明瞭な腫瘤を認めた.

$\mathrm{B} ： \mathrm{~T} 2$ 強調画像にて高信号を示す境界明瞭な腫瘤を認めた.

$\mathrm{C}$ ：造影 MRI 画像にて被膜が造影されていた。 


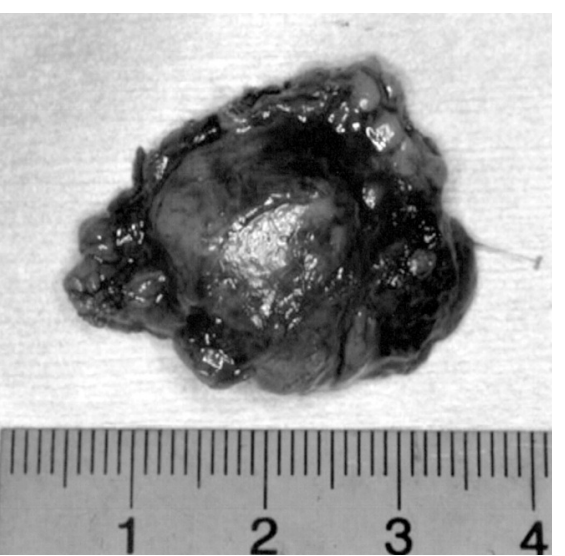

写真 3 摘出標本写真 $15 \times 13 \times 11 \mathrm{~mm}$ 大，弾性軟，表 面は平滑で舌下腺内に存在していた.

り解剖学的に超音波検査が困難であっ たため, MRIによる画像診断を行った。 池田ら ${ }^{8)}$ は MRI を撮影し, かつ手術的 治療が施行され, 病理組織学的診断が下 された唾液腺腫瘍 105 例を検討した結 果, 辺縁整であり, 内部信号不均一を示 し, T1 強調像で低信号, T2 強調像で高 信号を示す場合, 多形腺腫と診断する必 要条件であると報告している. 本症例で は池田らの必要条件を満たしており, 舌 下腺良性腫瘍のなかでも多形腺腫の可 能性が高いと臨床診断をした。

多形腺腫は周囲組織との境界が比較 的明睹で線維性被膜を有し, 癒着も軽度 であることから外科的に摘出すること が有効な手段とされている ${ }^{9)}$ 。しかし, 線維性被膜の外に小結節をつくる可能 性や, 線維性被膜による被包が不完全な ことがあり, 可及的に周囲健常組織を含 めて摘出する必要性も報告されている ${ }^{10)}$. 本症例では術中迅速組織診断にて多形 腺腫との病理組織学的診断を得たため, 腫瘍周囲の舌下腺を含めた摘出術を行 った.

現在術後 1 年 9 か月が経過しており， 再発なく経過良好であるが, 数十年の経 過を経て再発した報告 ${ }^{10,11)} や 10$ 年経 過の後再発し悪性化した報告 ${ }^{12)} も$ もる ことから今後も注意深く経過観察を行 う必要があると考えている.
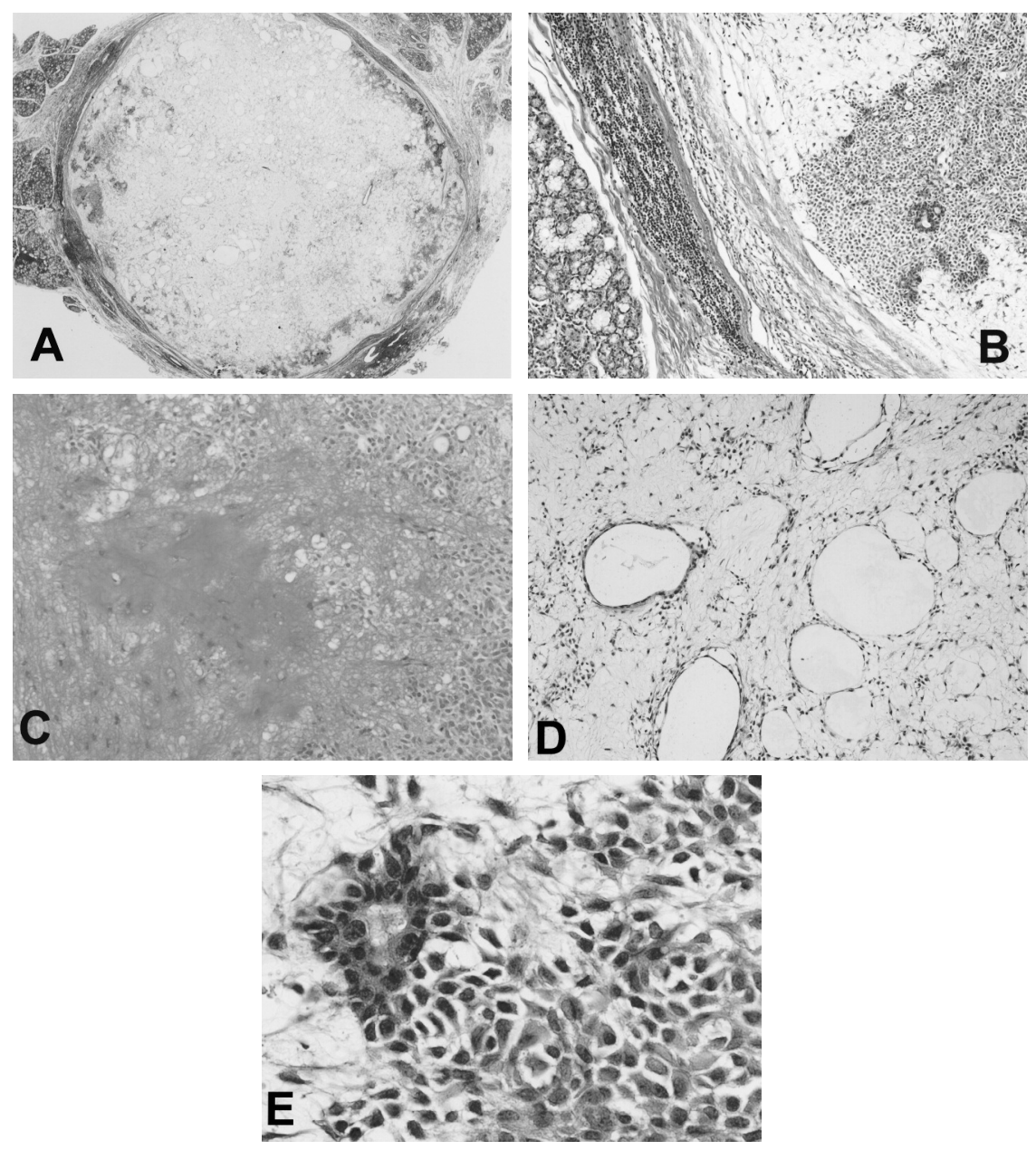

写真 4 病理組織像

$\mathrm{A}, \mathrm{B}$ ：腫瘤は薄い線維性被膜に全周を被われており, 被膜外への腫瘍細胞 の進展は認められない（H-E染色 $\mathrm{A} \times 10, \mathrm{~B} \times 100)$.

C：腫瘍は部分的に軟骨様成分を含み, アルシアンブルー染色陽性の粘 液腫様の間質を多量に伴っている（アルシアンブルー染色 $\times$ 200).

$\mathrm{D}, \mathrm{E}$ ：腫瘍細胞の大部分は類円形から紡錘形の核偏在傾向のある異型性の 乏しい腫瘍性筋上皮細胞が豊富な間質を伴う網状パターン増殖する 像から成り, 小囊胞の形成が認められる. また部分的に好酸性物質 を腔内に認める導管上皮細胞と周囲の腫瘍性筋上皮細胞の配列から なる二相構造も認められる（H-E 染色 D × 100, E × 400）。

表1 Armed Forces Institute of Pathology（AFIP）における多形腺腫の部位別発生 率抢よび全唾液腺腫瘍の部位別発生率

\begin{tabular}{|c|c|c|c|c|c|}
\hline & 耳下腺 & $\begin{array}{l}\text { 顎下腺 } \\
\end{array}$ & 舌下腺 & 小唾液腺 & 総数 \\
\hline 多形腺腫 & $4359(69 \%)$ & $657(10 \%)$ & $10(0.16 \%)$ & $1277(20 \%)$ & 6303 \\
\hline $\begin{array}{l}\text { その他の } \\
\text { 良性腫瘍 }\end{array}$ & 1207 & 68 & 4 & 444 & 1723 \\
\hline 良性腫瘍総数 & 5566 & 725 & 14 & 1721 & 8026 \\
\hline 悪性腫瘍 & $2656(32 \%)$ & $510(41 \%)$ & $33(70 \%)$ & $1634(48 \%)$ & 4833 \\
\hline $\begin{array}{l}\text { 良性腫瘍, } \\
\text { 悪性腫瘍の総数 }\end{array}$ & 8222 & 1235 & 47 & 3355 & 12859 \\
\hline
\end{tabular}


表2 本邦における多形腺腫の大唾液腺での部位別発生率

\begin{tabular}{|c|c|c|c|}
\hline & $\begin{array}{l}\text { 耳下腺 } \\
\end{array}$ & 顎下腺 & 舌下腺 \\
\hline 白川ら (1984) 6) & 114 & 75 & 2 \\
\hline 坂下ら (1991) 3) & 128 & 41 & 1 \\
\hline 内山ら (1995) 13) & 10 & 10 & 0 \\
\hline 鈴木ら（2006） 9) & 30 & 14 & 3 \\
\hline P. Gonzalezら (2007) 14) & 14 & 12 & 1 \\
\hline 山田ら (2006) 4) & 8 & 2 & 0 \\
\hline 川野ら（2006）15） & 27 & 9 & 0 \\
\hline 井上ら (2008) 5) & 76 & 25 & 1 \\
\hline
\end{tabular}

表3 大阪警察病院歯科口腔外科の全唾液腺腫瘍の部位別 発生率（1991～2007年）

\begin{tabular}{|c|c|c|c|c|c|}
\hline & 耳下腺 & 顎下腺 & 舌下腺 & 小唾液腺 & 総数 \\
\hline 多形腺腫 & 10 & 4 & 1 & 9 & 24 \\
\hline $\begin{array}{l}\text { その他の } \\
\text { 良性腫瘍 }\end{array}$ & 9 & 1 & 0 & 3 & 13 \\
\hline $\begin{array}{l}\text { 良性腫瘍 } \\
\text { 総数 }\end{array}$ & 19 & 5 & 1 & 12 & 37 \\
\hline 悪性腫瘍 & $5(21 \%)$ & $8(62 \%)$ & $5(83 \%)$ & $13(52 \%)$ & 31 \\
\hline 総数 & 24 & 13 & 6 & 25 & 68 \\
\hline
\end{tabular}

\section{結語}

今回舌下腺に発生した多形腺腫を経験したので若干の文 献的考察を加えて報告した。

\section{謝辞}

稿を終えるにあたり, 病理組織学的に貴重なご指導および ご教示を頂きました大阪警察病院臨床病理科部長, 辻本正彦 先生に厚く御礼申し上げます。
本論文の要旨は第 39 回日本口腔外科学会近畿地方会 (平成 20 年 6 月, 神戸市) において発表した。

\section{引用 文 献}

1) Evan, R.W. and Cruickshank, A.H.: Epithelial Tumors of the Salivary Glands. W.B. Saunders Company, Philadelphia, 1970, p58-76.

2) Gary, L. Ellis, Paul, L. Auclair.: Surgical Pathology of the Salivary Glands. Vol 25. W.B. Saunders Company, Philadelphia, 1991, p135-164.

3）坂下英明，宮田 勝，他：唾液腺腫瘍 411 例の病理 組織学的検討. 日口診誌 2: 284-301 1991.

4）山田慎一, 松尾長光, 他：唾液腺腫瘍の臨床統計的 検討. 日口診誌 1: 42-49 2006 .

5）井上庸夫，江口智徳，他：大唾液腺腫瘍 198 例の臨 床検討. 耳鼻臨床 101: 107-1132008.

6）白川正順, 藍沢茂雄：唾液腺腫瘍の臨床病理学的研 究一多形性腺腫の組織型と予後との関係を中心にし て. 歯科ジャーナル 19: 95-104 1984.

7）小島和行, 服部睦行, 他：唾液腺病変が疑われたと きの画像診断の進め方. INNERVISION 22: 54-57 2007.

8）池田耕士，岩井 大，他：耳下腺多形腺腫の MRI. 耳鼻臨床 89: 479-484 1996.

9）鈴木美保，道 泰之，他：多形性腺腫 104 例の臨床 的検討. 口科誌 55: 34-41 2006 .

10）川村 康, 高井克熹, 他：煩粘膜に再発を繰り返し た多形性腺腫の 1 例. 日口外誌 33: 432-436 1987.

11) Shigematsu, H., Okada, N., et al.: Recurrent myoepithelioma 24 years after removal of a pleomorphic adenoma in the palate. J Oral Diag/Oral Med 19: 1871922006.

12）矢郷 香，朝波惣一郎，他：唾液腺腫瘍 56 例の臨 床・病理組織学的検討. 口科誌 56: 356-366 2007.

13）内山秀樹, 杉原一正, 他：多形性腺腫の臨床統計的 観察. 口科誌 44: 257-260 1995.

14) P. Gonzales, A., Tanaka, A., et al.: Clinicopathological study of epithelial salivary gland neoplasms: retrospective review of 156 cases. J Meikai Dent Med 36: 135-143 2007.

15）川野真太郎，大部一成，他：唾液腺腫瘍 151 例の臨 床統計的検討. 日口外誌 52: 393-400 2006 . 